\title{
Mentorship in a Canadian residency program: faculty and resident needs and experiences
}

\author{
Rosaleen Chun, MD, FRCPC, MHSc $\mathbb{1}$ - Kaylene Duttchen, MD, FRCPC • \\ Melinda Davis, BMed, FANZCA · Julia Haber, MD, FRCPC • \\ Jocelyn Lockyer, PhD, Ed
}

Received: 27 October 2016/Revised: 12 February 2017/ Accepted: 21 February 2017/Published online: 28 February 2017

(C) Canadian Anesthesiologists' Society 2017

\section{To the Editor,}

We read with interest the recent manuscript by Ergun et al. ${ }^{1}$ on mentorship in anesthesia. We report here similar findings from our survey that was developed to help design a local formal program. Both faculty and residents were surveyed.

With the help of local survey experts and test volunteers, a 27-item survey was created with the following domains: past and current experience, perceived value, desired traits for a formal program, barriers to successful mentorship, rewards/benefits of mentorship. Responses were based on a five-point Likert scale, ranging from $1=$ very satisfied or strongly agree to $5=$ very dissatisfied or strongly disagree, with $3=$ neutral. Based on local institutional requirements under the Tri-Council Policy Statement (TCPS2), article $2.5{ }^{2}$ this work was deemed a quality improvement project. $^{3}$

R. Chun, MD, FRCPC, MHSc ( $₫) \cdot$ K. Duttchen, MD, FRCPC .

M. Davis, BMed, FANZCA · J. Haber, MD, FRCPC

Department of Anesthesia, Foothills Medical Center, Calgary,

AB, Canada

e-mail: rosaleen.chun@albertahealthservices.ca

R. Chun, MD, FRCPC, MHSc

Libin Cardiovascular Institute, Foothills Medical Center,

Calgary, AB, Canada

K. Duttchen, MD, FRCPC

O'Brien Institute for Public Health, University of Calgary,

Calgary, AB, Canada

M. Davis, BMed, FANZCA

Hotchkiss Brain Institute, Calgary, AB, Canada

J. Haber, MD, FRCPC · J. Lockyer, PhD, Ed

Department of Community Health Sciences, University

of Calgary, Calgary, AB, Canada
The final survey was disseminated to all department faculty and residents. Participation was voluntary. Data was analyzed via SPSS version 22.0 software (IBM Corp, Armonk, NY, USA). The completely de-identified data were collected from March 2014 through May 2014.

The response rate was $119 / 160(74 \%)$ faculty and $33 / 39$ (84\%) residents. In all, 15/29 (52\%) resident respondents were female, in contrast to $40 / 106$ (38\%) of faculty.

There were currently informal mentoring relationships for 23/106 (22\%) faculty and 11/29 (38\%) residents. Among the 11 resident respondents, 7 (64\%) were very satisfied with their relationship (3/11 were somewhat satisfied, and $1 / 11$ was neutral), in contrast to only $4 / 24$ (17\%) of the faculty. Of the remaining respondents, $6 / 24$ were neutral and 2/24 somewhat dissatisfied. If asked to participate in a formalized mentorship program, 24/28 $(89 \%)$ residents said they would agree to do so, in contrast to $73 / 106(69 \%)$ of faculty. A quarter of the faculty respondents (28/106) were unsure.

The desired traits of a future program are shown in the Table. Neither group wanted an arbitrarily assigned mentorship process, with both groups wanting to have input when choosing one another. More resident respondents, $21 / 30(70 \%)$ preferred one-on-one mentoring than faculty, among whom 44/107 (41\%) preferred comentoring.

Both faculty and resident respondents who had been mentors viewed the items "protected time to meet mentee", "education to develop mentorship skills", and "constructive feedback on my mentoring skills" as important (somewhat/very) for enhancing the mentorship. A separate research mentor was desired by 20/30 (67\%) of residents and 92/104 (88\%) of faculty.

Our brief survey shed light on current mentoring on one modern Canadian anesthesia residency. At least one-third 
Table Desired traits of a proposed mentorship program

\begin{tabular}{|c|c|c|c|c|c|}
\hline & & Faculty $(\%)$ & $n$ & Residents (\%) & $n$ \\
\hline \multirow[t]{4}{*}{ Structure of Relationship } & One/one & $53(49)$ & 107 & $21(70)$ & 30 \\
\hline & One Mentor/group & $10(9)$ & & $2(6)$ & \\
\hline & Co-mentor one resident & $28(26)$ & & $4(13)$ & \\
\hline & Co-mentor/group of residents & $16(15)$ & & $3(10)$ & \\
\hline \multirow[t]{4}{*}{ Assignment of Mentor/Mentee } & Both mentor/mentee assigned by program lead & $12(11)$ & 108 & $7(23)$ & 30 \\
\hline & Mentor has choice in choosing mentee & $3(3)$ & & $1(3)$ & \\
\hline & Mentee has input in choosing mentor & $13(12)$ & & $2(6)$ & \\
\hline & Mentor/mentee both have choice & $80(74)$ & & $20(66)$ & \\
\hline \multirow[t]{5}{*}{ Frequency of Meetings } & Annually & $0(0)$ & 108 & 2(7) & 30 \\
\hline & Bi-annually & $22(20)$ & & $12(40)$ & \\
\hline & More frequently & $26(24)$ & & $5(16)$ & \\
\hline & As needed & $38(35)$ & & $7(23)$ & \\
\hline & Other & $22(20)$ & & $4(13)$ & \\
\hline \multirow[t]{3}{*}{ Site of meetings } & At workplace & $23(22)$ & 106 & $4(13)$ & 30 \\
\hline & Outside workplace & $12(11)$ & & $7(23)$ & \\
\hline & Either & $71(67)$ & & $19(63)$ & \\
\hline \multirow[t]{3}{*}{ Matching for gender } & Agree (strongly/somewhat) & $15(14)$ & 107 & $3(10)$ & 29 \\
\hline & Neutral & $47(44)$ & & $14(48)$ & \\
\hline & Disagree (strongly/somewhat) & $45(42)$ & & $12(41)$ & \\
\hline
\end{tabular}

of residents were already in an informal mentor/mentee relationship, and most were satisfied with it. Like the findings of Ergun et al., ${ }^{1}$ our residents wished to have an active role in choosing a mentor and preferred one-on-one mentorship. In addition, based on their overall willingness to participate in a formal program, they showed that mentorship is valued.

In contrast, relative dissatisfaction in current informal mentoring relationships by faculty was an unanticipated finding and may be related thematically to their strong responses toward a lack of protected time, concern about mentorship skills education, and feedback. That $41 \%$ of the faculty preferred a co-mentoring structure could be seen by faculty as a shared commitment. This finding may be in line with the excellent report by Alisic et al., ${ }^{4}$ in which the concept of mentorship groups or networks is raised, allowing more fine-tuned mentorship that not only considers the seniority of the resident but the distinction between the mentee's dynamic professional and personal needs. 4

Although our findings are locally based, our program is structured like many others. That is, resident-training education is not financially remunerated and takes time. Faculty mentorship in this survey may have represented further personal and professional opportunity costs to those who were unsure about participating.

Perhaps revisiting the current traditional model of a dyadic mentorship structure in this modern era is warranted. Mentorship networks certainly would support both the residents and the needs of faculty who are timeconstrained. Future possibilities may also include distance mentorship ${ }^{5}$ with the advances of technology, social media, and global telecommunication.

Conflict of interest There are no commercial or non-commercial affiliations that may be perceived as a conflict of interest by the authors.

Editorial responsibility This submission was handled by Dr. Gregory L. Bryson, Deputy Editor-in-Chief, Canadian Journal of Anesthesia.

Funding There was no funding for this project.

Other associations There are no other associations by the authors.

\section{References}

1. Ergun S, Busse JW, Wong A. Mentorship in anesthesia: a survey of perspectives among Canadian anesthesia residents. Can J Anesth 2017; DOI:10.1007/s12630-017-0816-1.

2. Canadian Institutes of Health Research; Natural Sciences and Engineering Research Council of Canada; Social Sciences and Humanities Research Council of Canada. Tri-Council Policy Statement. Ethical Conduct for Research Involving Humans. December 2010 (Article 2.5). Available from URL: http://www. pre.ethics.gc.ca/pdf/eng/tcps2/TCPS_2_FINAL_Web.pdf (accessed February 2017). 
3. Alberta Innovates. ARECCI: A Project Ethics Community Consensus Initiative 2015. Available from URL: http://www. aihealthsolutions.ca/outreach-learning/arecci-a-project-ethicscommunity-consensus-initiative/ (accessed February 2017).

4. Alisic $S$, Boet $S$, Sutherland $S$, Bould $M D$. A qualitative study exploring mentorship in anesthesiology: perspectives from both sides of the relationship. Can J Anesth 2016; 63: 851-61.
5. Jaffer U, Vaughan-Huxley E, Standfield N, John NW. Medical mentoring via the evolving world wide web. J Surg Educ 2013; 70: 121-8. 